\title{
Perception of the effects of drug use among adolescents
}

\author{
Sandu Mihaela Luminița \\ “Ovidius" University of Constanta, Romania \\ mihaela_naidin@yahoo.com
}

\author{
Rus Mihaela \\ “Ovidius" University of Constanta, Romania \\ psiholog_m@yahoo.com
}

\author{
Rus Ciprian Vasile \\ $\mathrm{PhD}$., Independent Researcher
}

\begin{abstract}
At the global level, drug use and trafficking are a dynamic phenomenon, being strongly influenced by a multitude of social and economic factors. and in Romania, drug use and trafficking present new forms of manifestation, requiring increasingly varied approaches, being known as a complex phenomenon, characterized by permanent mutations. If, some twenty years ago, Romania was known as a state where only drugs were transited, in the last ten years, our country has been transformed into a market for drug use, especially heroin. Even though our country is below the European average for drug use, the latest studies conducted by the National Drug Agency indicate a lifetime prevalence of $4.3 \%$ for any type of drug in the general population, while among the population for 16-year-old students, this type of prevalence stands at $10 \%$, which shows significant increases in drug use in Romania, at the level of the entire population, but especially among the young.
\end{abstract}

Keywords. perception, effects, drugs, consumption, adolescents

\section{Introduction}

The dynamics, dimensions and characteristics of drug use in Romania are aspects that underpin the government policy in this field. Therefore, the intervention of the society must focus on at least four dimensions: social, economic, political and, not least, moral.

Addiction is an increasingly visible phenomenon, with wide and sometimes serious consequences at the individual and community level, and in this quality it highlights a series of hypotheses and perspectives regarding both the substances and the situations in which they are related. creates dependence, but also types and modes of consumption. It can be said about the drug problem in Romania that the period passed, indeed romantic, in which there were several voices who argued that drug addiction would be a minor problem, that we are more a 
transit channel to the western market, that a the kind of constraints external to the individual, of which the economic one would be the most effective in keeping it away from expensive drugs.

The World Health Organization (WHO) considers the drug to be the substance which, absorbed by a living organism, modifies one or more functions and whose use creates physical and mental dependence, but also serious disorders of mental activity, perception and behavior.

All drugs are considered to have two aspects in common:

- the initial effect of pleasure, of a very short duration, insignificant compared to the subsequent effects of extreme danger;

- serious, disastrous effects on health.

According to Ardelean (2001), drugs are defined as "natural or synthetic substances used by consumers for their action on the psychic (psychotropic action) as stimulants or sedatives of mental activity, modifying sensations and perceptions." (Ardelean, H, 2001, p. 4)

Trying to find the most complete and complex definition of drugs, Cristina OtovescuFrăsie (2008) identifies several acceptances of the term drug (Otovescu-Frăsie, C, 2008, pp. 309-321). She says that:

1. in a broad sense, the drug designates any substance (natural or artificial) which by its chemical nature causes the alteration of the functioning of an organ;

2. in a restricted sense refers to substances that cause tolerance and dependence.

3. In the usual language, the term drug refers to psychoactive substances, especially the illegal ones. The most popular drugs are cannabis, opiates, and hallucinogens.

Lupu and Zanc (1999), in addition to the definition given to drugs: "natural or synthetic substances used by consumers for their psychotropic action", consider that they modify the psychic functions through their influence on the attention, the quality of the sensations and emotional life, the idea and the imagination. (Wolf, I., Zanc, I., 1999, p. 181).

J. Molto and C. Radel (1995 beside Lupu and Zanc, 1999) considered that there are a number of factors that lead the individual to drug use, the authors grouping them into two broad categories:

\section{Socio-cultural factors:}

- the search for unusual pleasures by transgressing the prohibition and the taste of risk;

- belonging to a group that accepts consumption and drug users;

- the search for a spirituality by isolation from the world;

- the way to protest against something or someone;

- social isolation, insecurity, non-integration, living exclusively at present.

\section{Individual factors}

- most often refers to the vulnerability of individuals before drug interaction:

- low intolerance or tolerance to frustration;

- the urgent need to obtain satisfaction;

- pathological aggression;

- maladaptation, up to deviant behaviors;

- the relations between parents and children are disturbed;

- psychopathological disorders of variable severity, such as adolescent crises, psychopathy, schizophrenia, etc.

The reasons why some people are attracted to the drug are extremely different and difficult to explain, but what can be easily accepted is that they represent a major danger to the human body, a real trap for both those who are aware, but especially for the uninformed. 
Under the influence of drugs, consumers have the impression that they have a greater capacity for work, a more obvious creativity, young people consider that their performance, including sexual ones, that their anxieties disappear, an apparent calm is established where relations with family or friends they improve, all of which are just illusions that soon turn into the most real nightmare.

\section{Causes and effects of drug use}

We can talk about a multi-cause nature of drug use, due to the fact that up to this moment it was not possible to isolate a certain category of factors with a clear determination at the beginning of drug use. Addiction also affects those with financial difficulties and those who do not face such a problem, the level of education is not a determining factor, and the enumeration can continue.

Perhaps the easiest to detect among the multitude of factors are those of a social, interpersonal nature. At all ages, one element is curiosity, consumption may arise from the desire to try something different, new. At the same time, the absence of a socialization program, of succession of different activities from the recreational-cultural sphere, can generate boredom, which can lead to the consideration of consumption as a possible alternative.

In a society in which non-values are cultivated through mass-media, the most powerful medium of influence, terrorism determines extreme attitudes, from the need to live the feeling of importance, to be different from the others. The risks involved in purchasing and using drugs are considered to be challenging. The media has a negative contribution by promoting the idols of the young generation, drug users. Excessive promotion leads to the development of tolerance towards the behavior itself, which can have the effect of adopting it without reservation, unconditionally, in certain situational contexts and personality particularities.

In Maslow's pyramid of needs, the need for belonging can lead to the adoption of this type of behavior, giving pressure to the group of friends, the "gang", especially in the case of young people, for a false appreciation. The availability of the drug is an important causal factor, because at this time, the drugs are distributed not only in high schools and other environments, but also in elementary schools, which has a dramatic consequence of decreasing the age of onset of consumption. An initiative to implement video monitoring systems and compulsory contracts with companies to ensure the security of the respective perimeters is crystallizing. However, those involved in the drug distribution process are particularly creative and inventive, successfully managing to avoid the fragile school security system.

The social environment is also responsible for the etiology of drug use in many consumers. In conjunction with personality factors, the social environment can determine drug use as a means of escape from everyday life, from problems that seem to have no rational and efficient solutions.

At the same time, the altered family environment may be the prerequisite for the onset of drug use. The reasons are numerous and unfortunately, very common due to their frequency: divorce of parents, abandonment perceived by children or adolescents when parents go abroad to work, physical or emotional abuse, etc.

Parental attitudes are equally responsible for the onset of drug use behavior in pre and adolescent ages. The absence of behavioral supervision, of discreet monitoring of the entourage has as a consequence the integration of the young man in a group where he can be found, without this being necessarily a beneficial one for his subsequent personal evolution. 
The reduction of time spent with children, due to the very demanding program from a professional point of view, has the effect of impoverishing the family relations between parents and children, negative interactions between them. Also, inconsistent or excessively severe discipline rules are followed by the desire to escape from an overly restrictive environment, the possible solution being drug use, favored by an inappropriate entourage.

A conflicted, tense environment leads to the isolation of the young man, who begins to seek refuge in other groups, which he considers tolerant, where he feels accepted, without being judged. From here until the drug use is a very small distance, and the border between socially desirable and undesirable behavior is very blurred.

Another predisposing factor is the family history of behavioral problems, in which the fingerprint is visible and constitutes a favorable field for intervention from outside, in the form of the alternative that generates the addiction.

\section{Types of discriminatory behaviors}

Discrimination refers to the differences made in social life on behalf of certain groups, considered unacceptable by the majority, because they violate social norms and the principle of equality before the law, even when certain subgroups of the population justify them (Boudon, R., 1996). Discrimination is caused by lack of knowledge, intolerance, prejudice and is closely linked to stigmatization, labeling of people.

Discrimination is the difference and separation imposed on individuals or minority groups, aiming at marginalizing or isolating them, in relation to the majority of individuals in the social group (Enăchescu, C, 2007).

In the Dictionary of psychology (Porot, A, Porot, M, 1999) discrimination is defined in social psychology as representing the particular attitudes and behaviors that one individual or group manifests towards another individual or group, most often on the basis of characters, attributed to prejudice rather than objectively identified.

Discrimination is the differentiated treatment applied to a person by virtue of his or her real or supposed belonging to a certain social group. Discrimination is an individual action, but if the members of the same group are treated in a similar way, it is also a social pattern of aggregate behavior. In science, the term refers generally to prejudicial treatment, with negative effects on the target.

\section{The research tool}

The research method used was the sociological survey, and the instrument applied was a questionnaire.

The data recorded on the basis of the questionnaire were collected through the structured, uninominal, "face-to-face" interview technique. In order to carry out this interview, the aim was to ensure confidentiality, as well as to preserve the anonymity of the interviewed persons.

\section{Design of the questionnaire}

The questionnaire is addressed to teenagers and comprises several sections aimed at:

- data on the socio-economic level of the students;

- assessment of the degree of identification of drug types;

- assessment of knowledge, attitudes and practices regarding the illicit consumption of such substances and the effects associated with the consumption;

- information regarding the need for drug prevention and assistance programs;

- the availability of young people to volunteer in specialized centers for drug addicts. 


\section{The objectives of the study}

The objectives of the study were to evaluate the social perception of drug users, to identify ways to reduce the phenomenon of social exclusion, to identify the ways of recovering the addicts at the macrosocial level in order to social reintegration and to reduce the exclusion phenomenon.

\section{Participants in the study}

The research was carried out in the high school in Constanta. The sample consisted of 50 randomly selected subjects, aged 15-20 years, of which 52\% were boys and $42 \%$ were girls.

Table 1. Frequency of subjects according to gender

\begin{tabular}{|ll|r|r|r|r|}
\hline & & Frequency & Percent & $\begin{array}{c}\text { Valid } \\
\text { Percent }\end{array}$ & $\begin{array}{c}\text { Cumulative } \\
\text { Percent }\end{array}$ \\
\hline Valid & male & 26 & 52.0 & 52.0 & 52.0 \\
& female & 24 & 48.0 & 48.0 & 100.0 \\
& Total & 50 & 100.0 & 100.0 & \\
\hline
\end{tabular}

$20 \%$ of the respondents were 15 years old, $18 \%$ - 16 years old, $32 \%$ - 17 years old, $10 \%$ - 18 years old, $14 \%$ - 19 years old and only $6 \%$ were 20 years old.

Table 2. The frequency of the subjects according to age

\begin{tabular}{|c|c|c|c|c|c|}
\hline & & Frequency & Percent & $\begin{array}{c}\text { Valid } \\
\text { Percent } \\
\end{array}$ & $\begin{array}{c}\text { Cumulative } \\
\text { Percent }\end{array}$ \\
\hline \multirow[t]{7}{*}{ Valid } & $15 \mathrm{yrs}$. & 10 & 20.0 & 20.0 & 20.0 \\
\hline & 16 yrs. & 9 & 18.0 & 18.0 & 38.0 \\
\hline & $17 \mathrm{yrs}$. & 16 & 32.0 & 32.0 & 70.0 \\
\hline & 18 yrs. & 5 & 10.0 & 10.0 & 80.0 \\
\hline & 19 yrs. & 7 & 14.0 & 14.0 & 94.0 \\
\hline & 20 yrs. & 3 & 6.0 & 6.0 & 100.0 \\
\hline & Total & 50 & 100.0 & 100.0 & \\
\hline
\end{tabular}

\section{Analiza şi interpretarea rezultatelor}

Din diagramele de structura 1, 2 rezulta ca majoritatea adolescenţilor intervievaţi au intrat în contact macar o data cu drogurile legale. Ei sunt în necunoştinta de riscurile si efectele provocate de consumul de bauturi alcoolice şi tutun şi consideră că acestea sunt doar "mijloace ce ofera placere şi buna- dispoziţie".

\section{Analysis and interpretation of results}

From the structure diagrams 1, 2 it appears that most of the adolescents interviewed came in contact at least once with legal drugs. They are unaware of the risks and effects caused by the consumption of alcoholic beverages and tobacco and consider that these are only "means that offer pleasure and good disposition". 


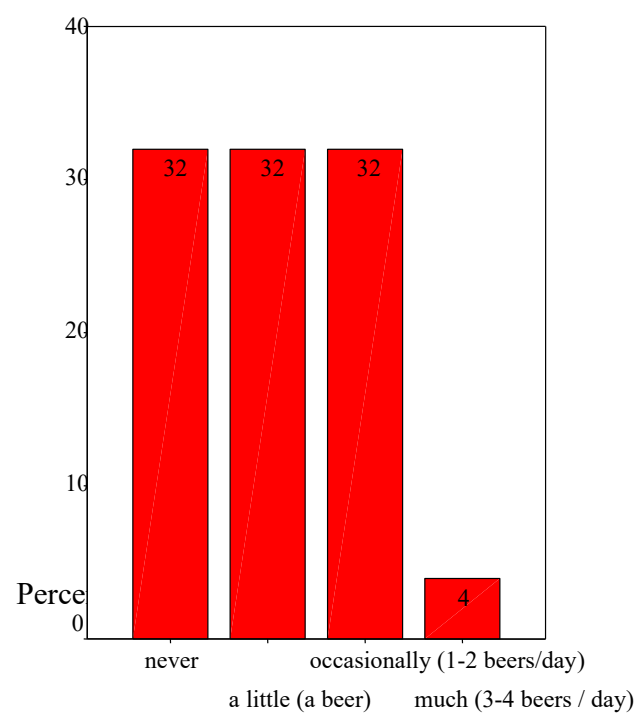

Figure 1. Do you consume alcohol?

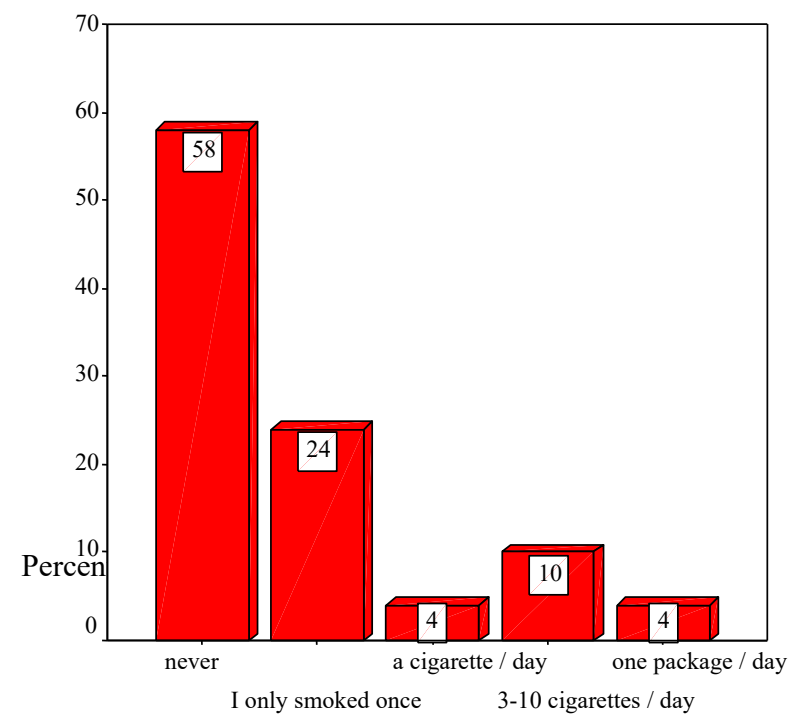

Figure 2 Do you smoke?

From the data obtained it was found that among adolescents there were subjects who resorted to the use of illegal drugs. $96 \%$ of adolescents stated that they had never used drugs, and $92 \%$ would never have tried this, while $4 \%$ had tried or used to use drugs occasionally (Figure 3, 4).

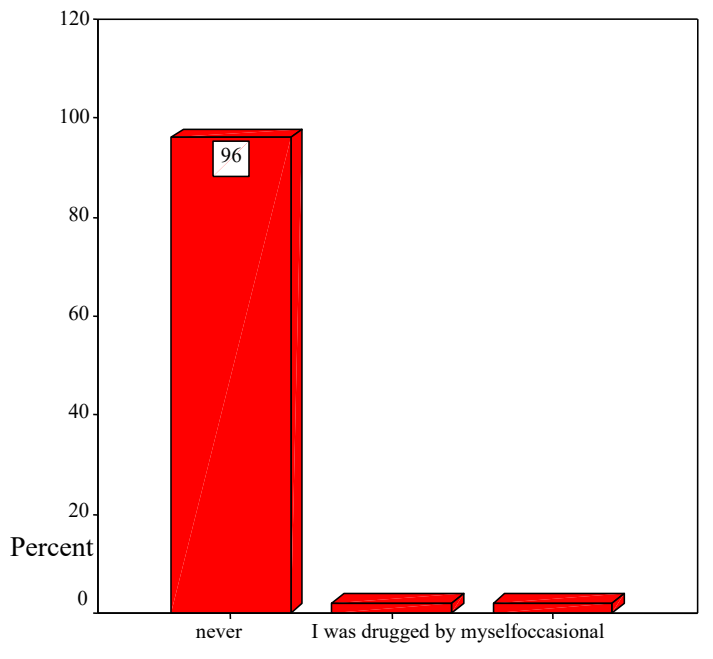

Figure 3. Do you get used to drugs?

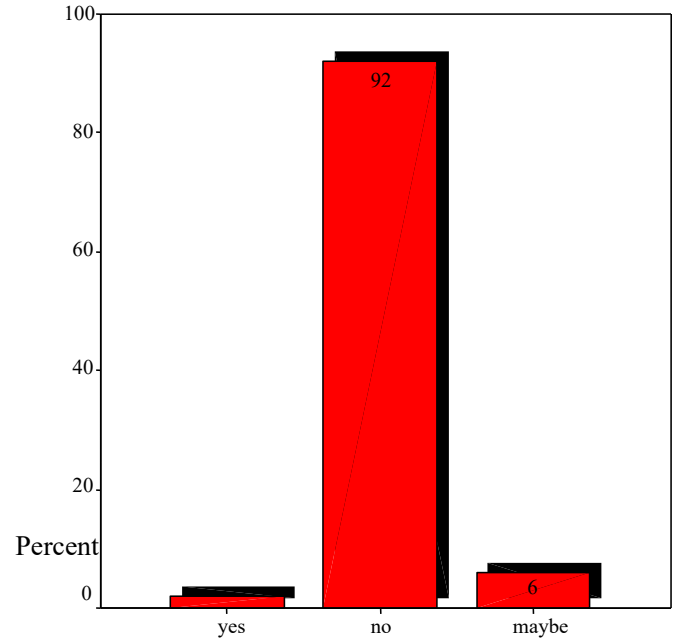

Figure 4. Would you be tempted to use drugs?

From the diagram below (figure 5) it turns out that most of the adolescents surveyed know about this scourge. This leads to the conclusion that if at the beginning of the 1990s this was a somewhat reduced phenomenon as a manifestation, after 15 years of transition, the use of drugs took on worrying dimensions. In this regard, a concentrated policy is required from all the factors responsible for preventing and combating trafficking and drug use in all social categories, especially those at risk. 


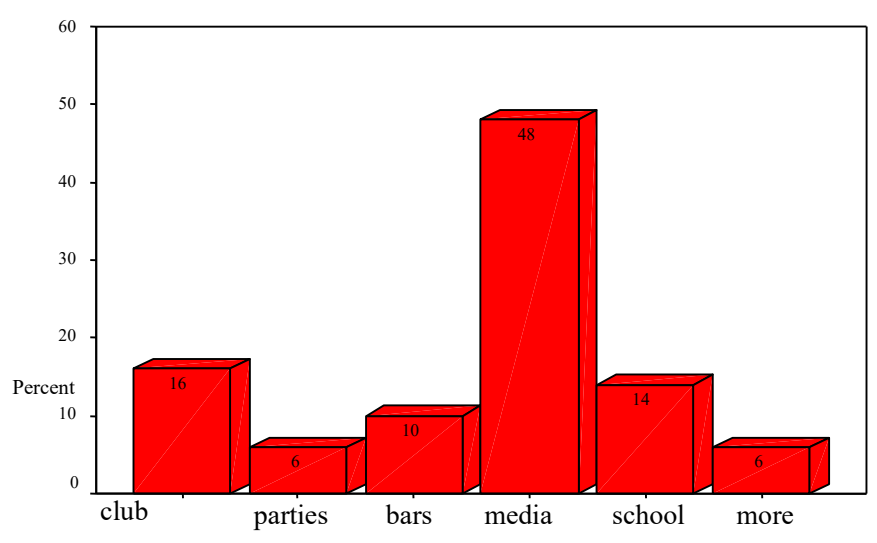

Figure 5. Where did you find out about the existence of drugs?

From the data collected and analyzed, in the graph below (figure 6) it is observed that, in the opinion of adolescents, the main internal factor favoring drug use is curiosity. It is recognized by the majority as the main motive of temptation and is one of the main internal causes of drug use. The construction of drug prevention programs should take into account this central pivot of adolescent motivation (which is, in fact, one of the age-specific domains).

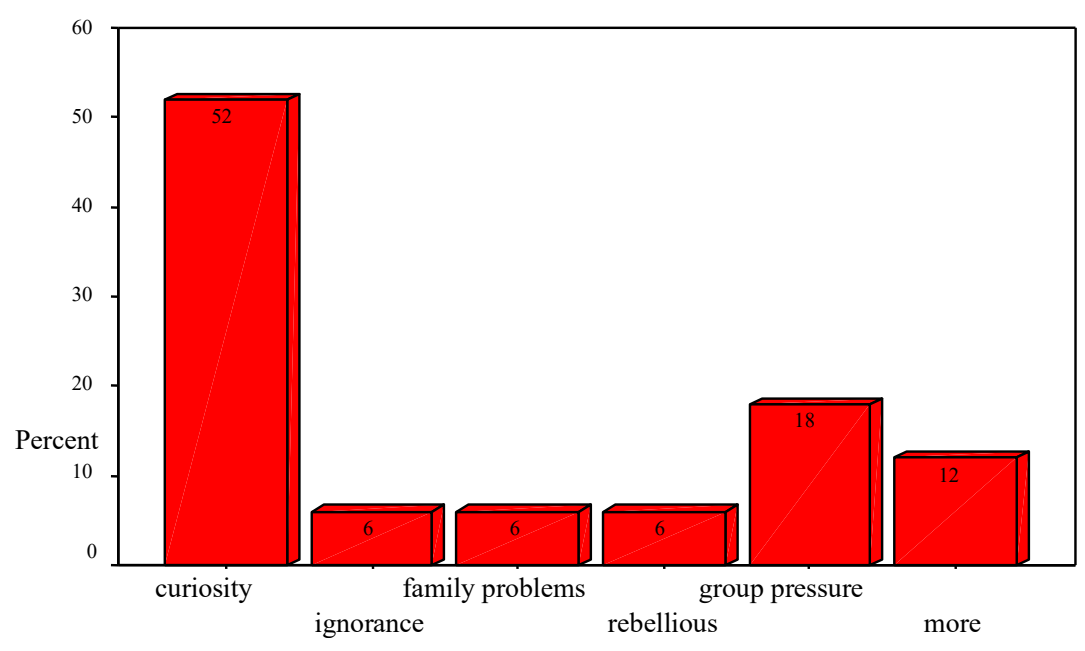

Figure 6. What are the reasons that would cause you to use drugs? 


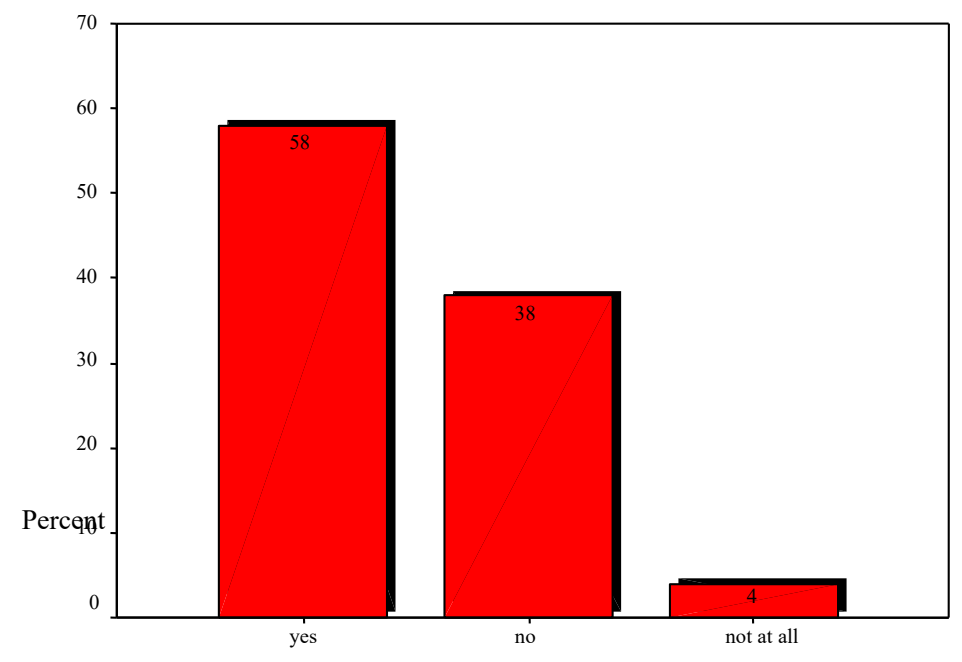

Figure 7. Do you know the effects of drug use on the human body?

It was observed that $58 \%$ of the adolescents interviewed are aware of the risks of drug use. I think there is a need to improve the information strategy among students regarding the consequences of risky behaviors (Figure 7).

\section{Case study}

John Doe, 18 years of age, addicted to heroin, was admitted to the detoxifying section of the $\mathrm{Al}$ hospital. Obregia, due to the fact that the detoxification treatment could not be carried out in Constanta.

The FIC (Community Care Foundation) therapeutic team traveled to section 16 to establish a first contact with the client and to evaluate him. It was evaluated from the biological, psychological, social and legal point of view by applying EUROP-ASI (Annex 4) with the following results:

John Doe is a 3-year-old heroin addict (2 years he smoked, 3 months he inhaled "foil", 1 year he was given intravenously). Has 2 attempts to detoxify in the background, followed by the return to the same living environment and short periods of abstinence. He had no overdoses, no associated somatic or mental illness. He comes from a functional family (harmonious relations with parents, sister and relatives), is professionally integrated (graduated from 12 classes, works as an installer together with his father and uncle). John Doe is also involved in a 4-and-a-half-year relationship, a relationship that is currently strained due to drug use. From a legal point of view, John Doe has a lawsuit for theft (he stole to get money for the drug).

The EUROP-ASI score - 5 shows an average level of addiction, falling within the selection criteria of the zero drug program. Applying the motivational balance, discussing the advantages and disadvantages of consumption, I noticed that John Doe's motivation for maintaining abstinence is genuine (he sincerely wants to give up consumption to give his girlfriend a chance). 


\section{Disintoxication}

Following the nonsubstitutive detoxification treatment (17.02.2010-12.03.2010) within section 16, the withdrawal symptomatology was easily overcome. Having experienced the previous relapses that invariably occurred after 1-4 months of abstinence, when he considered that mental dependence is easily overcome without any help, John Doe gladly accepts the proposal to be included in the outpatient therapy program.

\section{Post-treatment}

John Doe came to FIC with his family (parents and friend) where he was again evaluated bio-psycho-socially by the therapeutic team made up of doctor, psychologist and social worker. Monitoring of opiate metabolites in the urine confirms abstinence. The psychosocial evaluation indicates the solid motivation for maintaining abstinence and the good level of social insertion. He was offered bi-weekly sessions of individual, family and couple therapy. The starting point of the therapeutic sessions was represented by the identification and appropriate formulation of John Doe's problems with the active participation of the support persons (family, couple partner, group of friends).

The individual therapy was of cognitive behavioral type, with the main objective being to identify the stimuli and the situations of high risk and to develop the skills needed to cope with them.

The therapist together with the patient tried to identify the most frequent situations that determined the previous relapses. John Doe identified as a potential danger first and foremost the group of consumer friends who have the generosity to offer a free first dose but also the parties (the beginning of the nightclub consumption) or conflict situations with the friend and family.Once the risk situations were clarified, the therapist together with the client tried to sketch out coping methods, which were efficiently practiced at home.

Due to the importance that John Doe attaches to his relationship with his partner, couple therapy has naturally played a central role, with the aim of diminishing the couple's tensions. It is worth noting the readiness of his friend to tone down his behavior and to make efforts to support him.

The patient was taught to write a craving journal to record the times when he or she was confronted with the craving for drugs, the triggering factors, the thoughts and feelings and strategies applied to resist the temptation.

\section{John Doe's patient craving journal}

Here are some moments:

The girl wants to break away from him, saying she doesn't trust him anymore. He felt sad, forsaken, deceived, misunderstood, just as he was trying to abstain. He thought that no one loves him, does not understand him, that a dose of drugs could help him to overcome this condition more easily. The need to consume, the appetite was growing stronger. He managed to overcome the craving by thinking first of all of the family, as much as they might suffer.

At the next therapeutic session he felt the need to discuss the issue of couple as a potential high risk situation for consumption.

Another moment with great potential for risk, perhaps even the most difficult, is when he met a consumer friend who offered to "honor him with a dose". "At first I felt tingling all over my body and suddenly I remembered how I was eating, something told me to go to shoot, as if I had a little devil on my shoulder and he would tell me go, go, go ... ".

I was thinking that I was being put in front of that obstacle that had to happen time and time again. But I also kept an eye on the ball I had in my hand and I remembered that for 
drugs I lost what I had most precious, my friend. However, the patient went with the consumer to the scale of the block with the intention of injecting. "I prepared the goods, I gave my friend a half dose, the other half stopped it for me." This moment generated a state of great anxiety, a strong struggle between the desire to drug and the thought that a new dose could be the beginning of a relapse. "I had the power to stop myself in time from a situation that could be fatal, if I fired then, now I am sure that I would get it over with. But I said I don't do it and I'm gone. I had a meal voucher and bought 5 beers to make it easier to overcome the desire to consume".

At the next therapeutic session, the client was particularly happy because he had managed to overcome this critical situation. He was encouraged and congratulated for his ability to cope with the risk of relapse, discussing a possible future situation and ways to cope and say NO.

Also, within the family therapy topics were addressed regarding the situations of high risk, the active involvement of the family in the therapeutic process. The two moments presented were discussed, highlighting the client's evolution and progress.

Shortly after, John Doe meets a friend who is a heroin addict who offers him "merchandise." "I felt confident in myself and nothing can cause me to do what I did before and I told him to leave me alone. I left where I had a job, but on the way I stayed and thought about what I did and I think I did exactly what I should and should always do. I went on a road and I am determined to go to the end and I will not deviate from this road that I started".

In this situation, the client felt safe managing to apply the skills developed during the therapeutic sessions.

The client was evaluated after 3 months of post-treatment therapy: the couple's relationship has broken down, but he maintains his abstinence, goes to work, is integrated in the family, has a circle of non-consuming friends. Currently the client is abstinent for 5 months following the post-treatment program.

\section{Conclusions}

The data collected and analyzed in the above research refers to adolescents' perceptions of the causes that determine drug use, the amplitude that this worrying phenomenon has among young people. It is important to research the opinions of adolescents due to the increasing spread of drug use among this age group, but also to find out what are the reasons, temptations, explanations carried in their world.

Adolescents consider that the refuge in vices is a solution of problems, of adolescent loneliness, that it is an escape from the pressure of social life, a fun, being strongly influenced by advertisements. The feeling of temporary good mood, boredom, or lack of credible identification patterns throws them into the drug net.

Thus, young people mistakenly believe that using drugs once is not dangerous, as they cannot become addicted, as it is easy to stop, if you want, as only weak individuals become addicted, your alcohol and drug use solve problems, as drugs make you feel more important.

Synthesizing information about adolescents' perceptions of their own generation and their (real or symbolic) relationships with the drug world, detailing and analyzing this information about the magnitude of the phenomenon, the lack of information on the negative effects of drugs, their connection to and transmission of the virus, etc., we can extract information necessary to build a strategy to prevent drug use in adolescents. 


\section{References}

[1] Ardelean, H. (2001), Droguri şi toxicomani, Oradea: Editura Europrint, p. 4.

[2] Campbell Ross, Copiii noştri şi drogurile, Curtea Veche, Bucureşti, 2001;

[3] Dicţionarul Explicativ al Limbii Române, Editura Univers Enciclopedic, Bucureşti, 1996;

[4] Dr. Cristian Bellu- Bengenescu, "Adolescenţii si toxicomania" (volum coordonat de Gilles Ferreol), Iaşi, Editura Polirom, 2000;

[5] Dragan, Jenica, Dicţionar de droguri, Editura Naţional, 2000;

[6] Enăchescu, C. (2007), Tratat de psihopatologie, Ed. Polirom, Iaşi

[7] Lupu, I., Zanc, I. (1999), Sociologia medicală. Teorie şi aplicaţii, Iaşi: Editura Polirom, p. 181.

[8] Otovescu-Frăsie, C. (2008), Consumul de droguri ilicite în România versus dreptul la viață, în Studii de Drept Românesc, 20 (53), nr. 3-4, p. 309-321.

[9] Rus, M., Tasențe, T., Rus, C.V. (2019). Preventive behaviors and attitudes of the children as active participants in road traffic, Acta Universitatis Danubius. Administratio 11(1) 2019.

[10] Rus, M., Tasențe, T., Sandu, M. (2019). Study Regarding the Perception on the Personality Traits in Managerial Decision Making, Journal of Danubian Studiesand Research, Vol 9, No 2 (2019)

[11] Sandu M., Tasențe, T., Postaru, D., Ciacu, N. (2014). Domestic Violence - A Current Problem of Romanian Society, Acta Universitatis Danubius. Communicatio, Galati, Vol. 8, nr. 1, 2014 